\title{
Network Marketing Strategies in Sale and Marketing Products Based on Advanced Technology in Micro- Enterprises
}

\author{
M. Rezvani, S. Ghahramani and R. Haddadi
}

\begin{abstract}
New products based on modern technologies (high-tech), in order to enter the market, face a number of challenges such as high investment required for research and development of these products, high cost of labor force, high cost of products, making profit at advanced stages, low life expectancy, high level of associated risks and required innovation. In terms of marketing these products, issues such as centralized decision making by the manager or the owner, dynamic environment, existence of larger competitors with higher resources and influence in the market, high expectation of customers and lack of resources are just some of the issues to mention.

In this study the effects and functionality of network marketing strategies such as reduction of costs, increase in the rate of sales, brand making, job creation, effective networking, high level of innovative potentials, and increase in liquidity as the result of growth of sales; which itself is obtained by viral marketing and its expansion to a social networking site with exchanges of social capital has been investigated. The statistical population are a number of small scale companies providing microfiber Nano silver cleaning cloths based in the city of Tehran. The research method which has been used in this research is qualitative research method.

The results of the research show that by providing a favorable reward plan in network marketing, microenterprises offering high-tech products can overcome many of their problems and difficulties in presenting, selling and promoting their products in the market.
\end{abstract}

Index Terms-Microenterprises, network marketing, social network, social capital, viral marketing.

\section{INTRODUCTION}

Fundamental changes during the past century have had a staggering effect on every aspect of human life. Management systems and commercial relationships are some of the most important factors in advancement of technology, information and methods of work that have experienced fundamental transformation and evolution. The marketing system with daily innovation in creating new and modern methods, have created and provided a new environment for marketing mix (product, price, distribution and promotion) of a variety of products or services to the consumer's market.

Network marketing is a modern method of selling

Manuscript received December 12, 2016; revised January 20, 2017.

M. Rezvani and S. Ghahramani are with the University of Tehran, Iran (e-mail:m.rezvani@ut.ac.ir, sh.ghahramani@ut.ac.ir).

R. Haddadi is with the Board of Sita Tejarat, Iran (e-mail: raminhaddadi@gmail.com). products with the use of social communication tools and networks that promotes its products with the use of verbal marketing that has eliminated traditional intermediaries and no longer requires expensive advertisement procedures to achieve its goals [1]-[5]. Network marketing is a way for spreading information on a product to consumers via social communication channels. Trading between the seller and the consumer in the market only occurs when the consumer possesses a certain level of information on the product. Companies often spend enormous amounts on promotion of their new products. The important point to mention is that, with increasing cost of advertisements, the final price of the product is also increased which in effect reduces the profit of the company. Therefore, in order to transfer information to the consumers, companies look into alternative low-cost methods for promoting and positioning their products in the market. One of these alternative methods is to use human relations within social networks efficiently. By using network marketing method, not only companies no longer need to spend heavily on advertisements, the potential buyers will also experience a higher level of trust and security in their shopping behavior by obtaining information from people around them [6]-[9].

Taking into account the information provided on abilities and capabilities of network marketing and special marketing of new High-Tech products, this study intends to look into and identify functions and solutions associated with network marketing of high-tech products in microenterprises. In order to implement the results, companies offering microfiber Nano silver cleaning cloths as a high-tech product in Tehran have been selected for the purpose of this study.

\section{LITERATURE REVIEW}

\section{A. The Concept of Network Marketing}

The concept of network marketing of the healthy, legal type is used in some cases as equivalent to "direct marketing." In this method, the producer sells its goods through the people and customers themselves rather than through distribution agents with a high percentage of commission. Thus, a network of customers who are willing to help the producer with the sale task while benefitting themselves take charge of the goods marketing and sale tasks via a contract. In some cases in the literature, network marketing is also referred to as "multi-layer marketing" [3].

Network marketing is one of the several ways of activity in the area of goods and service distribution. In this method, 
the company employs a network of distributors to sell its products to the user. The distributors sell the products to the final user not at a fixed retail store but through interpersonal communication. They are also allowed to make and manage their sales force through "recruitment" and "training" of other participants in order to sell products [3], [10]. The literature review of network marketing has provided in Table I.

\begin{tabular}{|c|c|c|c|}
\hline Concept & Researcher & Year & The Emphasized aspects and Variables \\
\hline \multirow{5}{*}{ 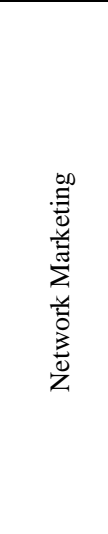 } & [3] & 2008 & $\begin{array}{l}\text { Behavioral Growth and potential revenue aspects in both single-level and binary structure } \\
\text { of the network assessment }\end{array}$ \\
\hline & [2] & 2008 & $\begin{array}{l}\text { Behavioral Growth and potential revenue aspects in both single-level and binary structure } \\
\text { of the network assessment }\end{array}$ \\
\hline & [11] & 2007 & $\begin{array}{l}\text { Network Marketing by increasing communication skills, presentation skills, motivation } \\
\text { levels, and the inner personal skills are potential tools for the socio - economic } \\
\text { development. }\end{array}$ \\
\hline & [9] & 2007 & $\begin{array}{l}\text { Attracting customers to their interested products and giving representative ship through } \\
\text { online-based marketing expert system. }\end{array}$ \\
\hline & [12] & 2007 & $\begin{array}{l}\text { Attracting more customers using the network marketing and the development of previous } \\
\text { models by using data on the network, and Ranking network neighbors into smaller } \\
\text { groups. }\end{array}$ \\
\hline
\end{tabular}

\section{Social Network or Social Capital}

Social networks consist of powerful interpersonal communication such as friendship, kinship, and long-term cooperation with members of other groups or companies based on social communication [13]. The Literature review of social capital has provided in Table II.

Sociological studies of native entrepreneurs confirm that social capital is the very social networks. Network capital can be described as complex networks of the society capable of guiding and screening information based on cultural identity. Social capital also addresses the control of allocation of scarce resources available to entrepreneurs. Social capital forms behavior based on cultural values, so that the more powerful the social capital, the richer the cultural values [14].

TABLE II: LITERATURE REVIEW OF SOCIAL CAPITAL

\begin{tabular}{|c|l|l|l|}
\hline Concept & \multicolumn{1}{|c|}{ Researcher } & Year & \multicolumn{1}{c|}{ The Emphasized aspects and Variables } \\
\hline \multirow{3}{*}{$\bar{s}$} & {$[15]$} & 2010 & $\begin{array}{l}\text { Positive and negative effects and impact of structural dimensions of social capital or } \\
\text { dense and sparse networks in creating incremental and fundamental innovations. }\end{array}$ \\
\cline { 2 - 4 } & {$[16]$} & 2008 & $\begin{array}{l}\text { Mutual trust in social capital plays an important role in the acquisition of knowledge, } \\
\text { companies success and facilitation of knowledge flow compromise between companies, } \\
\text { and social capital plays and strategic role in building sustainable competitive } \\
\text { advantages }\end{array}$ \\
\hline
\end{tabular}

\section{Marketing in Small and Medium Companies}

Small and medium companies are one of the most important parts of job creation in the economy. It is very important, therefore, to increase conception of the key factors effective on their success. Review of the literature demonstrates that in order to achieve their goals, small and medium companies pursue marketing differently from the way in which large companies do it [17], [18], [19], [20].

Researchers all agree that marketing is different in small and medium companies than in large ones [21], [22], [23].
The operation of marketing is restricted in small and medium companies for many reasons. The reasons include low resources (like financial and human), conception of operation, skills, and insight [24], weak money supply, lack of marketing skills, company size, tactical and strategic problems concerning the customer [25], [26]. The Literature review of small enterprises has provided in Table III.

TABLE III: LITERATURE REVIEW OF SMALL ENTERPRISES

\begin{tabular}{|l|l|l|l|}
\hline Concept & Researcher & Year & The Emphasized aspects and Variables \\
\hline $\begin{array}{l}\text { Small } \\
\text { Enterprises }\end{array}$ & {$[27]$} & 2006 & $\begin{array}{l}\text { Small businesses have an inappropriate working physical condition, and organizational } \\
\text { health and safety management systems than large businesses, but on the other hand have } \\
\text { better psychological conditions. }\end{array}$ \\
\cline { 2 - 4 } & {$[28]$} & 2002 & $\begin{array}{l}\text { In terms of internationalization and market development, small businesses have some } \\
\text { major difficulties. Complementary assets are considered a threat to them. Marketing } \\
\text { skills, distribution and access to financial resources and mechanisms are some of their } \\
\text { main weaknesses and pricing level is one of their main strengths. }\end{array}$ \\
\hline
\end{tabular}

\section{SUMMARY}

Issues that retail companies are faced with include shortage of capital, high costs, and lack of experts. New products based on modern technology are also confronted with problems upon entry to the market such as great 
investment of the research and development sector, high workforce cost, high product prices, obtaining premature benefit, their short lifetimes, high risk-taking, and innovation. On the other hand, marketing these products is also affected by factors such as centralized decision-making on the part of the manager or owner, dynamic environment, presence of greater competitors with higher resources and effects on the market, customers' great expectations, and lack of effective resources. The network marketing strategy also has functions such as cost reduction, sale rate increase, branding, job creation, networking power, high innovation power, and money supply increase resulting from sale growth, made by viral marketing and its extension into a social network through social capital exchange.

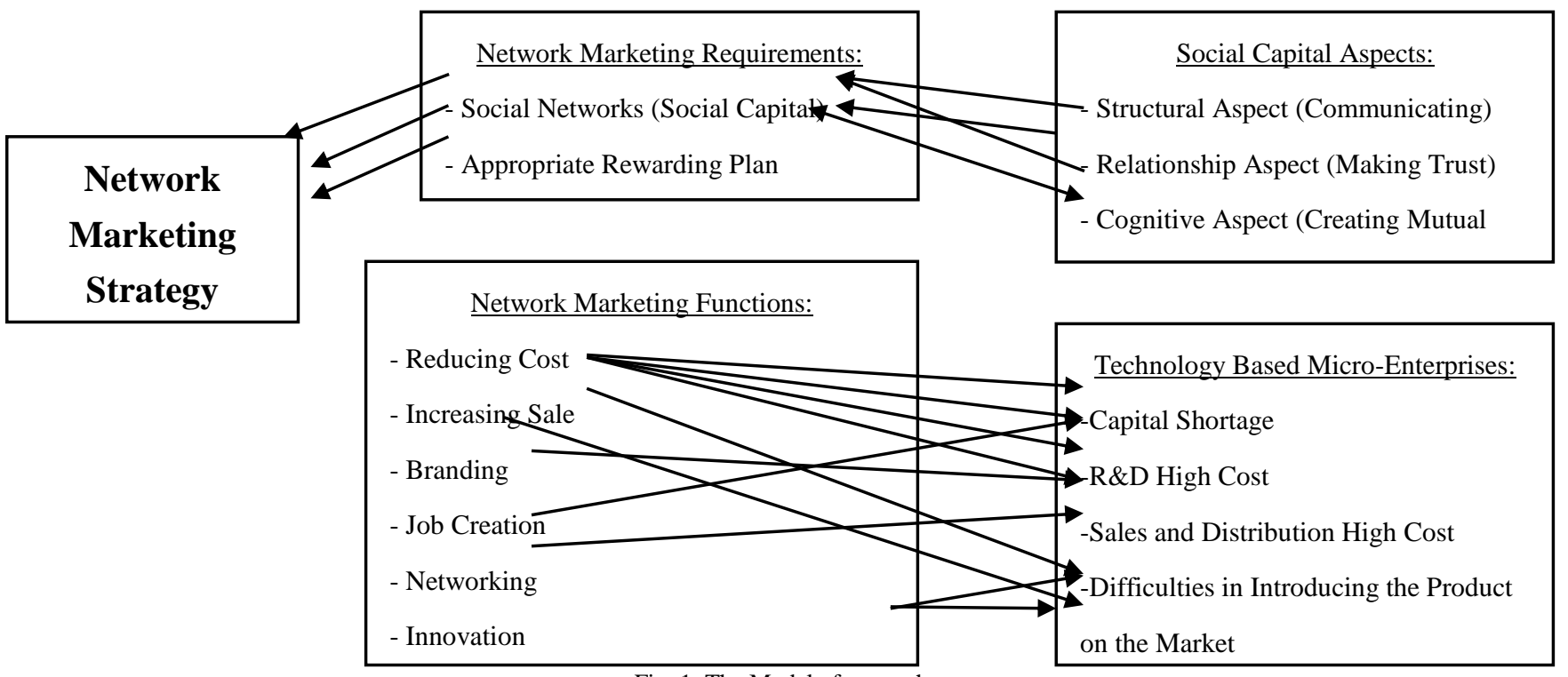

Fig. 1. The Model of research.

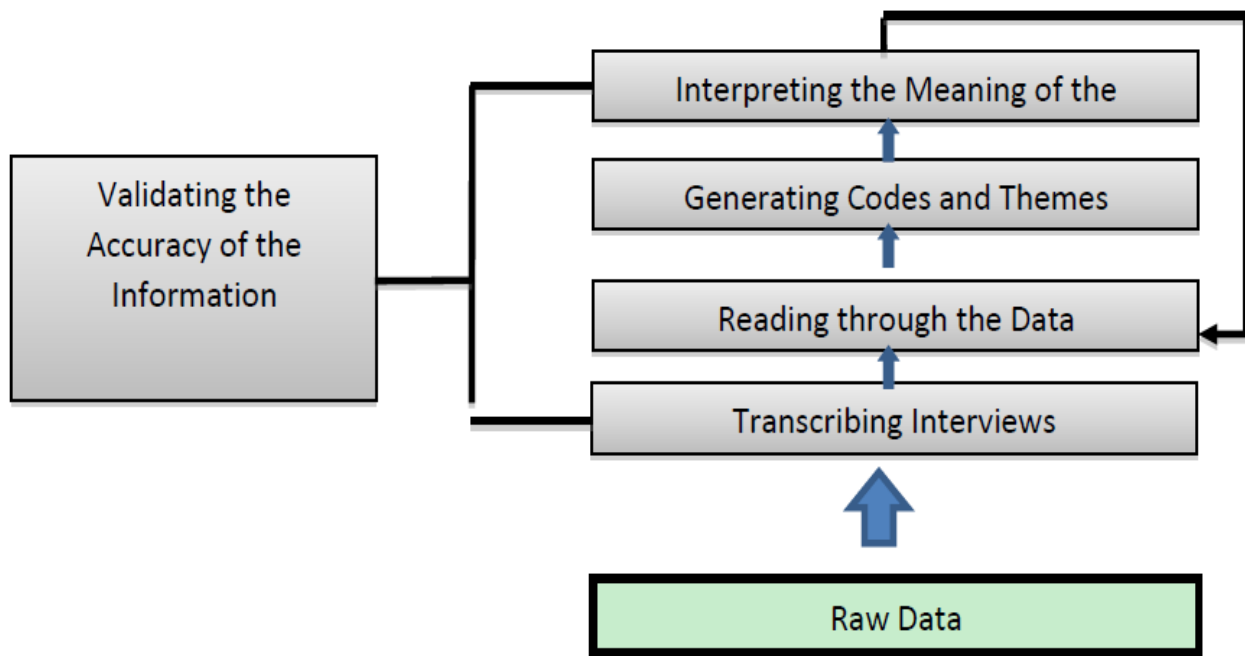

Fig. 2. Steps of qualitative data Analysis [29]

\section{3-8- METHOD OF INFORMATION ANALYSIS}

The method of qualitative content analysis and data and category coding has been used.

\section{3-8-1- Coding Method}

It was performed with the "open-axial" method in the following two steps:

- In the first step, open coding, we formed the information categories (classes) through fractionating and studying the information, and specified the core and subsidiary categories using the collected data.

- In the second step, we selected open coding for axial coding of a category, and investigated it as the core category or phenomenon at the center of the process, and then associated the rest of the categories to it.
Performing this step requires the coding table to be drawn. The diagram demonstrated the relationships between the causal conditions, strategies, environmental conditions, and particular grounds and resulting consequences.

In qualitative data analysis, the researcher states his interpretation of what he has seen, heard, and perceived, and tries to provide a picture of the problem under investigation including reports of different points of view, identification of several factors effective in a situation, etc. [29].

\section{RESUlts CONCERNING THE MAIN QUESTION}

The main research question is "what are the functions and solutions of network marketing for marketing and sale of new products based on advanced technology?" In view of 
the results obtained from the research, network marketing can have the following functions and solutions in marketing and sale of new products based on advanced technology in microenterprises, which have been included in the case study obtained from the theoretical foundations and field study of the companies under investigation:

\section{A. Functions of Network Marketing}

The functions of network marketing based on the theoretical foundations and qualitative research in this project include:

\section{1) Cost reduction}

One of the issues involved in microenterprises is their high costs. Analysis of the data obtained from the theoretical foundations and interviews in Coded Table demonstrates that man-to-man or network marketing leads to reduction of advertisement, distribution, and market research costs, costs concerning test of goods, sale unit training costs, costs concerning embellishment and decoration of the store showcase, and human force costs, which has been significantly effective on reduction of their costs and increase in their money supply.

\section{2) Sale Increase}

Based on the researcher's findings from the interviews made according to Coded Table and the theoretical foundations, sale volume and rate increased through further attraction of independent vendors and the value added made for users.

Confirming the above statements, [30] hold that actual products are used in the network marketing strategy, where the purpose is to increase sale and provide information on new products using a network of independent vendors. [5] also believes that products are presented in this strategy directly by the independent distributors to the final users, and they charge a commission in return for selling the products. Each of these distributors can also introduce other distributors, and the primary distributor also charges an amount as commission in return for the secondary distributor's sale, and value added is made for the sale network and users by the commissions paid.

\section{3) Product branding}

Based on the data obtained from this research according to Coded Table and the theoretical foundations, everybody agrees that network marketing proved very useful in identifying and introducing goods and their quality and efficiency to users.

Ref. [12] also hold that in network marketing, people provide their friends and acquaintances with information concerning products or services by verbally supporting them, and recommend that they use the products.

\section{4) Job creation}

Based on the researcher's findings from interviews made with cleaning industry companies with products based on modern technology, according to Coded Table and the theoretical foundations, network marketing will cause motivation and attraction of independent vendors and, finally, job creation by attracting independent vendors further and paying desirable commissions.

Ref. [30] Also hold that actual products are used in the network marketing strategy, where the purpose is to increase sale and provide information on new products using a network of independent vendors. Subsequently, [5] believes that products are presented in this strategy directly by the independent distributors to the final users, and they charge a commission in return for selling the products. Each of these distributors can also introduce other distributors, and the primary distributor also charges an amount as commission in return for the secondary distributor's sale, and value added will be made for the sale network and users by the commissions paid, and will lead to job creation.

\section{5) Viral marketing}

Based on the researcher's findings from the interviews made according to Coded Table and the theoretical foundations, face-to-face selling and marketing to family members, relatives, and acquaintances in man-to-man marketing, suggesting the function of viral marketing in network marketing, which has led to advertisement for the above users' knowledge and goods sale and distribution.

which is in complete accordance with [31] belief, who hold that in network marketing, people provide their friends and acquaintances with information concerning products or services by verbally supporting them, and recommend that they use the products. This state of affairs is also referred to as viral marketing.

\section{6) Networking}

Based on the researcher's findings from the interviews made according to Coded Table and the theoretical foundations, network marketing leads to relations made among family members and relatives and independent vendors, and these relations can result in networking.

Ref. [5] also believes that products are presented in this strategy directly by the independent distributors to the final users, and they charge a commission in return for selling the products. Each of these distributors can also introduce other distributors, and the primary distributor also charges an amount as commission in return for the secondary distributor's sale.

\section{7) Innovation}

Based on the researcher's findings from the interviews made according to Coded Table and the theoretical foundations, network marketing helps facilitate market research from the operational as well as cost reduction aspect through permanent, continuous relations between independent vendors and identify customers' instant and future needs, and finally helps the business innovate in the products. This is in line with [31] research, focused on the efficiency of network marketing in research on marketing and reduction of its costs.

\section{B. Money Supply Increase}

Based on the researcher's findings from the interviews made according to Coded Table and the theoretical foundations, network marketing causes sale to increase, and seeks to charge the users for the sold goods so that the independent vendors obtain their commissions faster. On the other hand, cost reduction is also one of the functions of network marketing. The sale increase and cost reduction functions lead to increase in the money supply of the company. 


\section{Use of Social Networks along with Social Capital Exchange}

Based on the researcher's findings from the interviews made according to Coded Table and the theoretical foundations, it is communication that makes the social network in network marketing, and it is social capital exchange that develops trust and sympathy in the network, and the common values and goals, such as higher product sale, are finally created.

Furthermore, [32] consider three dimension for intraorganizational social capital with an organizational approach: the cognitive dimension (creation of common values, which is one of the social capital concepts), relational dimension (development of trust and sympathy), and structural dimension (communication), which is in line with the researcher's findings.

\section{CONCLUSION}

As shown in Table IV, the functions which are found in the research have been provided in nine groups that have been extracted and interpreted through the interview coding program.

TABLE IV: NETWORK MARKETING FUNCTIONS FOUND IN RESEARCH

\begin{tabular}{|c|c|c|}
\hline No. & & Network Marketing Functions Found in Research \\
\hline \multirow{7}{*}{1} & \multirow{7}{*}{ Reducing cost } & Reducing the cost of advertising \\
\hline & & Reducing distribution costs \\
\hline & & Reducing the cost of market research \\
\hline & & Reducing the cost of product testing \\
\hline & & Reducing the unit cost of sales training \\
\hline & & Reducing or eliminating the shop's decoration \\
\hline & & Reducing human resource cost \\
\hline \multirow[t]{2}{*}{2} & \multirow{2}{*}{ Sale Increase } & Attract more independent retailers \\
\hline & & The added value created for independent dealers and distributors \\
\hline 3 & Branding & Product and brand recognition \\
\hline \multirow[t]{2}{*}{4} & \multirow{2}{*}{ Job Creation } & Attract more independent retailers \\
\hline & & Pay good commission \\
\hline 5 & Viral Marketing & Face to face Sales and marketing to relatives \\
\hline 6 & Networking & Networking with customers and independent distributors \\
\hline 7 & Innovation & Market research and understanding the customer needs \\
\hline 8 & Increasing Liquidity & Sell more products in cash while reducing costs \\
\hline 9 & $\begin{array}{l}\text { Using a Social Network with } \\
\text { Social Capital Exchange }\end{array}$ & Communicating, creating trust and shared values \\
\hline
\end{tabular}

\section{RECOMMENDATIONS FOR FUTURE STUDIES}

Regarding to the spatial scope of the study is limited to cleaning companies that their products are Consumer products or Fast Moving Consuming Goods (FMCG) and are based on Microfiber and Nano silver technology, Functions and network marketing strategies for other products based on advanced technology can be investigated. Moreover, we recommend that in future studies, generalizability of the findings of the research and application in a wider range of space, time and Industry $\mathrm{Be}$ checked.

\section{REFERENCES}

[1] N. Pedrood, H. Ahmadi, and H. A. Charafeddine, "Systematic profitability analysis of binary network marketing organizations," Direct Marketing: An International Journal, vol. 2, no. 2, pp. 81-96, 2008.

[2] H. A. T. Kiet and B. J. Kim, "Network marketing with bounded rationality and partial information," Statistical Mechanics and its Applications, vol. 387, Issue 19-20, pp. 4896-4902, 2008.

[3] Legara et al., "Earning potential in multi-level marketing enterprises," Statistical Mechanics and its Applications, vol. 387, issue 19-20, pp. 4889-4895, 2008.

[4] A.-G. Kwaku and L. M. De Luca, "Marketing's lateral influence strategies and new product team comprehension in high-tech companies: A cross-national investigation," Industrial Marketing Management, issue 37, issues 6, pp. 664-676, 2008.

[5] Han, "The application of fuzzy decision method in the evaluation of network Marketing," in Proc. Sixth International Marketing Conference on Fuzzy Systems and Knowledge Discovery, 2009.

[6] Saiffudin et al., "Social scenario of multi-level marketing in Bangladesh," Journal of Business Study, vol. XXVII, no. 1, 2006

[7] Zhiaqianng, "Research on network marketing pricing strategy of China's sporting goods enterprises," in Proc. International Conference on Computer and Communication Technologies in Agricultural Engineering, 2010.

[8] Wei et al., "Research on the ways of creative network marketing in ecommerce," in Proc. International conference on marketing and digital society, 2010.

[9] Y. H. Wang and M. Qi, "Research and design of network marketing system based on expert system," Grey Systems and Intelligent Services, pp. 1475-1478, 2007.

[10] Delgado, "The impact of the recruiting and training practices on the satisfaction and success in the network marketing distribution channel," Bell \& Howell Information and Learning Company, UMI 9956514, 2000

[11] P. Sreekumar, "A study of multilevel marketing (MLM), as a potential tool for socio-economic development," Institute of Chartered Financial Analysts of India, pp.181-184, 2007.

[12] Hill et al., "Network-based Marketing: Identifying likely adopters via consumer networks," Institute of Mathematical Statistics, vol. 21, no. 2, pp. 256-276, 2006.

[13] C. Lechner, M. Dowling, and I. Welpe, "Firm networks and firm development: The role of relational mix," Journal of Business Venturing, issue 21, pp. 514-540, 2006. 
[14] D. Foley, "Does culture and social capital impact on networking attributes of indigenous entrepreneurs?" Journal of Enterprising Communities, no. 3, pp. 204-224, 2008.

[15] A. Filieri, "Investigating the role of social capital in innovation: sparse versus dense network," Journal of Knowledge Management, vol. 14 , no. 6, pp. 891-909, 2010

[16] Mu et al., "Interfirm networks, social capital, and knowledge flow," Journal of knowledge management, vol. 12, no. 4, pp. 86-100, 2008.

[17] M. L. Bell and E. C. William, "The faltering marketing concept," Journal of Marketing, vol. 35, pp. 37-42, 2008.

[18] R. Brooksbank, D. A. Kirby, D. Taylor, and D. Evans-Jones, "Marketing in medium sized manufacturing firms: The state-of-theart in Britain," European Journal of Marketing, vol. 33, no. 1/2, pp. 103-120, 1999

[19] H. Liu, "Market orientation and firm size: An empirical examination in UK firms," European Journal of Marketing, vol. 29, no. 1, pp. 57 71,1995

[20] D. J. Pollard and M. W. Jemicz, "Marketing deficiencies and the internationalization of Czech SME's," International Journal of Entrepreneurship and Small Business, vol. 3, no. 3/4, pp. 400- 416.

[21] N. E. Coviello, R. J. Brodie, and H. J. Munro "An investigation of marketing practice by firm size," Journal of Business Venturing, vol 15 , pp. 523-545, 2000

[22] G. Audrey, D. Carson, and K. Grant, "SME Marketing in practice," Marketing Intelligence \& Planning, MCB UP Ltd, 2001.

[23] J. Hill, "A multidimensional study of the key determinants of effective SME marketing activity: Part 2," International Journal of Entrepreneurial Behaviour and Research, vol. 7, no. 6, pp. 211-235, $2001 \mathrm{~b}$.

[24] D. Carson and S. Cromie, "Marketing planning in small enterprises: A model and some empirical evidence," The Journal of Consumer Marketing, vol. 7, no. 3, pp. 5-18, 1990.

[25] I. Doole, T. Grimes, and S. Demack, "An exploration of the management practices and processes most closely associated with high levels of export capability in SMEs," Marketing Intelligence and Planning, vol. 24 no. 6, pp. 632-47, 2006

[26] J. D. Weinrauch, O. K. Mann, P. A. Robinson, and J. Pharr, "Dealing with limited financial resources: a marketing challenge for small business," Journal of Small Business Management, vol. 29, no. 4, pp.33-45, 1991.

[27] Sorensen et al., "Working in small enterprises - Is there a special risk?" Safety science, vol. 45, pp. 1044-1059, 2006.

[28] Bernoider, "Factors in SWOT analysis applied to micro, small-tomedium, and large software enterprises: An Austrian study," European Management Journal, vol. 20, no. 5, pp. 562-573, 2002

[29] J. W. Creswell, Research Design: Qualitative, Quantitative, and Mixed Methods Approaches, Sage Publications, Thousand Oaks, USA 2009.

[30] S. Li, B. Ragu-Nathan et al., "The impact of supply chain management practices on competitive advantage and organizational performance," Omega The International Journal of Management Science, vol. 34, no. 2, pp. 107-124, 2006.

[31] A. Jamshid, "Faghihsedighehsadat; scientific and leagal consideration of network marketing," Publication of Majd, 2008.

[32] J. Nahapiet and S. Ghoshal, "Social Capital, Intellectual capital and the organizational advantage," Academy of management Review, vol. 23 , no. 2, pp. 242-260, 1998 .

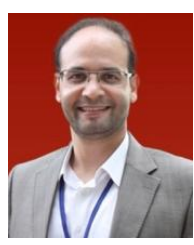

Mehran Rezvani graduated from University of Tarbia Modares (Iran), Faculty of management and Economics, International Marketing in 2010. He held a master diploma in industrial management in 2006 and he is a $\mathrm{Ph} . \mathrm{D}$. in International Marketing with the doctor degree. Presently he is Assistant Professor and Faculty Member in Faculty of Entrepreneurship, University of Tehran and teaches Entrepreneurial courses to MA and Ph.D. students. His research activity can be observed in the following achievements: A member of a National Elite Foundation of Iran; Select a research project titled "Business Model of Resalat Qarz Bank in terms of attracting and allocation of resources" as "The Practical Sample Model" in the twenty-fourth Festival of Research and Technology at Tehran University in 2015; "Dehkhoda Book of the Year" Award in the first period Humanity Science faculty members across the country for the book titled "International entrepreneurship" as one of five selected works published in Iran since 2012-2014 and receive appreciation of both the Minister of Science, Technology, Minister of labor, accompany with receiving reward from the Minister of social welfare and the Minister of Islamic culture and Minister of Ministry Of Science, Research And Technology in 2014; "Young Researcher" award at the twenty-third Festival of Research and
Technology of University of Tehran in 2014; Acknowledgement for the student thesis selection under the guidance of research at the university level in twenty third festival of University of Tehran, Written by Mr. Morteza Khazaeipool, confirmed by the head of University of Tehran in 2014; Certificate from the Deputy of the Ministry of Science, Research and Technology for being the scientific secretary of First National Brand and Knowledge-based Enterprises Conference on Science and Technology Park of Qazvin in 2013, etc.

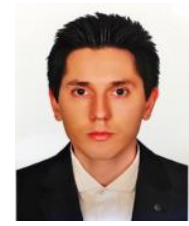

Shahram Ghahramani graduated from Institute for Management and Planning Studies (IMPS) in Business administration field in 2015. He's a Ph.D. candidate of Marketing at University of Tehran.

His got the diploma of Project Management from KASKERT/Germany. His areas of specialization are in marketing, export and import, international payments methods, international banking, brand management, SME's, international entrepreneurship.

He is Expert of International Department at City Bank (Shahr Bank) from Sep. 1, 2015 to Now.

He has published some papers such as: M. Aghaei, A. Asadollahi et al., "The impact of store brand price -image on retailer equity dimensions among the customers of Etka chain stores of Tehran," J. Basic. Appl. Sci. Res., vol. 3, no. 5, pp. 873-879, 2013; M. Rezvani, S H. Ghahramani et al., "An investigation of viral marketing effects on costumer-based brand equity in mobile market," Middle-East Journal of Scientific Research, vol. 18 , no. 3, pp. 376-381, 2013.

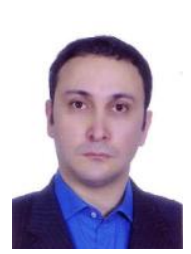

Ramin Haddadi has graduated in Entrepreneurship Management from University of Tehran, Faculty of Entrepreneurship (Iran) in 2013.

He was commercial manager and member of the Board of Triko Ramin Manufactoring and Export Company from 1992-1994; commercial manager of Triko Ramin Manufactoring and Export Company from 1994 to 1997; sales and marketing manager and member of the Board of Payam Peik Sadra from 1997 to 1999; The CEO and member of the board of Sorena Gostar Art \& Cultural Institute from 2005 to 2008 And He is commercial manager and member of the board of Sita Tejarat from 2008 to Now. 